\title{
Gender-based Study of Metadiscourse in Research Articles' Rhetorical Sections
}

\author{
Mahin Yavari (Corresponding author) \\ Islamic Azad University, Maragheh Branch, Maragheh, Iran \\ E-mail: mahin.yavari@gmail.com \\ Alireza Fard Kashani, MA. \\ University of Science \& Technology, Tehran, Iran \\ E-mail: fakashani1984@gmail.com
}

Received: 03-11- 2012

doi:10.7575/aiac.ijalel.v.2n.2p.77
Accepted: 01-01- 2013

Published: 01-03- 2013

URL: http://dx.doi.org/10.7575/aiac.ijalel.v.2n.2p.77

\begin{abstract}
This study investigated whether or not male and female writers of academic research articles were different in the use of interpersonal resources in English. In order to carry out the study, 32 applied linguistics research articles with the standard macrostructure of empirical research articles (Introduction, Method, Results, and Discussion/Conclusion) were selected from amongst the highest ranked journals. The results of the current study indicated that, with respect to both interactive and interactional features, there were no significant gender-based differences in the overall distribution of interpersonal resources in the four sections of the articles ( $p$-value> 0.05). It also confirmed the view that writing differences are not gender-specific, but rather section-specific. In this line, identification of male and female EFL learners' use of metadiscourse elements will provide guidelines to EFL teachers to tailor their teaching methods and avoid mismatches between classroom practices and learners' language use.
\end{abstract}

Keywords: metadiscourse; interactive resources; interactional resources; gender

\section{Introduction}

The term 'metadiscourse' was coined for the first time by Zellig S. Harris in 1959. Later on, a number of researchers such as Williams (1981), Vande Kopple (1985), Crismore (1989) and Hyland (2005) elaborated it much more. It has been widely defined as 'metalanguage' (Lyons, 1977), 'non-topical linguistic material' (Lautamatti, 1978), 'metatalk' (Schriffin, 1980), 'discourse about discourse' or 'communication about communication' (Vande Kopple, 1985), and 'signalling devices' (Crismore, 2004) among many other scholars' definitions. Nonetheless, very few studies offer a specific definition of metadiscourse, partly because it constitutes a fuzzy nature (Hyland, 2005a; Adel, 2006). Of all these descriptions about metadiscourse, Hyland (2005a, p. 37) proposes the most advantageous definition of metadiscourse: "Metadiscourse is the cover term for the self-reflective expressions used to negotiate interactional meanings in a text, assisting the writer (speaker) to express a view point and engage with readers as members of a particular community". In other words, in this new definition, he tries to show presence of the writer in the text and also the role of the reader in the construction of argument.

Closely intertwined with metadiscourse is gender-based analysis of metadiscourse and metadiscoursal resources which is practiced to clarify whether (or not) and how men and women resort to different strategies and discourse markers to express themselves through the medium of written or spoken language. From what literature shows, it is crystal clear that although numerous studies have investigated gender and spoken language use in different countries, little research is conducted about this phenomenon in a writing context and more specifically with respect to all the four sections of a research article (RA). As Swales (1990) puts it "RA has a dynamic relationship with all the other public researchprocess genres. Even when we leave aside private and semi-private communicative activities connected with the RA (cover letters, reviewer's reports, reprint requests, etc.), the RA still remains at the center of a spider's web" (p.177). Thus, the present study, which is part of a larger study, sought to fill the intended gap through answering the following question: Do male and female writers utilize metadiscoursal resources differently in the four sections of research articles? The rationales and significances behind this current study are two-folded. At the theoretical level, this study sheds light on an area of research in English for Academic Purposes addressed extensively by language researchers and linguists worldwide. At the practical level, the proposed study would help teachers understand learners' approaches to academic writing and type of metadiscoursal elements or markers they adopt in this process.

\section{Theoretical Terms and Background}

\subsection{Metadiscourse Taxonomies}

In history of metadiscourse, several metadiscourse taxonomies have been suggested "so as to classify metatextual elements according to their form, meaning, or function" (Hernandez Guerra \& Hernandez Guerra, 2008, p. 100). Most of these metadiscourse taxonomies are based on Halliday's Systemic Functional Linguistics (SFL), primarily developed 
by Michael Halliday (e.g. Crismore and Fransworth, 1990; Crismore et al., 1993; Hyland, 1998b, 2000, 2005a; Vande Kopple, 1985). The purpose of SFL is to examine the organization of language in relation to its use by means of analysing texts in their sociocultural contexts. According to Eggins (2004), SFL has four main principals:

1. That language is functional

2. That it's function is to make meaning

3. That these meanings are influenced by the social and cultural context in which they are exchanged

4. The process of using language is a semiotic process, a process of making meanings by choosing (p. 3).

In this functional-semantic approach, language is used for the realization of three broad metafunctions: ideational, interpersonal, and textual. Ideational meaning is related to the real word and the representation of world's ideas, experiences by means of language. But, Interpersonal meaning expresses the writer's and reader's way of behaving as well as their attitudes towards each other. Textual meaning is also related to the coherence, how we can organize the written or spoken genre to produce coherent genre (Eggins, 2004; Hyland, 2005).

To Halliday, as stated in Hyland (2005a, p.27), all three metafunctions operate dependently not independently, because "discourse is a process in which writers are simultaneously creating propositional content, interpersonal engagement and the flow of text as they write". Hyland (2005a) also points out that analysts by separating propositional content from metadiscourse resources, try to classify metadiscourse items into two groups of textual, i.e., resources used for organizing and making coherence of text, and interpersonal one, i.e., resources used for expressing writers attitudes.

\subsubsection{Hyland's Taxonomy}

Although Crismore et al.'s classification has been an influential one in metadiscourse studies, but it has its own limitations and critics. In an attempt to amend some of the shortcomings, Hyland (2005a) has proposed his own model of metadiscourse markers (see Table 1). Hyland (1998) modified Crismore et al.'s (1993) schema and introduced comprehensive model of metadiscourse. His metadiscourse model (1998) entailed two sub-divisions: textual and interpersonal metadiscourse. But, after a while, Hyland and Tse (2004) rejected the duality of metadiscourse functions (textual and interpersonal). This rejection by Hyland and Tse (2004) has been considered as an interesting point for most of scholars following the model. They claimed that all metadiscourse is essentially interpersonal because they need to take into account "the reader's knowledge, textual experiences, and processing needs and that it provides writers with an armoury of rhetorical appeals to achieve this" (p.168). To this end, Hyland (2005a) has made a change in his taxonomy by adopting Thompson's (2001) model of interactive and interactional instead of textual and of interpersonal respectively. He has made a clear distinction between interactive and interactional metadiscourse in which both have an interpersonal functions with the former concerned with guiding the readers through an unfolding discourse and the latter dealing with the writer's opinion and their interactions with their readers. Here, Hyland's interactive and interactional metadiscourse are comparable to Halliday's (1994) textual and interpersonal metafunctions.

Another important fact in Hyland's taxonomy is that it comprises of stance and engagement markers which are used by writers to convey their stance towards both the content and the audience of the text. This taxonomy suits the purposes of this study best, as it acts as a shield against controversies, such as the distinction between metadiscourse and propositional content (e.g., Williams, 1981; Crismore, 1983; Vande Kopple, 1985) and its advocating nature to view all metadiscourse as interpersonal. And moreover it is a move from traditional treatment of metadiscourse towards a model that can capture the underlying principles of academic writing. Table 1 shows this interpersonal model of metadiscourse.

Table 1. An Interpersonal Model of Metadiscourse (Hyland, 2005a, p. 49)

\begin{tabular}{lll}
\hline \multicolumn{1}{c}{ Category } & \multicolumn{1}{c}{ Function } & \multicolumn{1}{c}{ Examples } \\
\hline Interactive & Help to guide the reader through the text & Resources \\
\hline Transitions & Express relations between main clauses & in addition; but; thus \\
\hline Frame markers & Refer to discourse acts, sequences or stages & Finally; my purpose is \\
\hline Endophoric markers & Refer to information in other parts of the text & Noted above; see fig; in section 2 \\
\hline Evidentials & Refer to information from other texts & According to X; Z states \\
\hline Code glosses & Elaborate propositional meanings & Namely; e.g.; such as \\
\hline Interactional & Involve the reader in the text & Resources \\
\hline Hedges & Withhold commitment and open dialogue & Might; perhaps; about \\
\hline Boosters & Emphasize certainty or close dialogue & In fact; it is clear that \\
\hline Attitude markers & Express writer's attitude to proposition & I agree; surprisingly \\
\hline Self-mentions & Explicit reference to author(s) & I; we; my; me; our \\
\hline Engagement markers & Explicitly build relationship with reader & Consider; note; you can see that
\end{tabular}




\subsection{Studies on Gender}

As the literature shows, amongst individual factors, gender can influence the choice of interpersonal metadiscourse resources. According to Grey (1998), the starting point for the comparison of the differences of male and female behaviour in using linguistic forms dates back to 1970s. Since then, many studies have been devoted to differences between men and women. While the volume of research into gender differences with respect to metadiscourse resources is not very large, most research has been conducted on oral communication; typically examining conversation and concluding that men and women use different linguistic devices available to them in interactions. Holmes' (1984) study on English speakers' essays revealed that the use of interpersonal metadiscourse was prominent in female writer's essays. They used 'attitude markers', 'commentary markers' and 'interpretive markers' including code glosses, illocution markers and announcements more than men, but textual features namely, connectives, sequencers, topicalizers and reminders followed with hedges were used more by male writers. Similarly, Crismore et al. (1993) compared the use of metadiscourse in persuasive essays written by U.S. male and female university students. The results suggested that both genders used interactional metadiscourse more than interactive one, but female used them more than males. This is in line with the findings of Holmes' (1984) study in which female writers' priority was significant in using interpersonal type of metadiscourse. They identified male writer's uncertainty by using more hedges and thereby interest in writer-reader interaction. Holmes $(1988,1989)$ studied the issue of politeness and revealed that gender patterns by considering hedges, tag questions, apologizes and compliments as politeness strategies. The prevalence of women in using these features as politeness strategies was evident in that study.

In an investigation of connections between gender and conversation among English speakers, Tannen (1994) showed that women tended to use more supportive and cooperative styles and men enjoyed more competitive styles which resulted in male dominance in mixed gender talks. Janssen and Murachver (2004) in an investigation of the effect of gender on writing asked undergraduate learners to write passages involving socio-emotional content and political debates. Here, the topic played a role in male and female learners' language use; female writers tended to show their preferential features in socio-emotional content, but male preferential features were prominent in politics. They concluded that topic restriction can remove the trace of writer's gender. In another study, Herring and Paolillo (2006) conducted research on web logs restricted to diary and filter. They investigated this genre to understand whether there was any correlation between genre, stylistic features and gender. They found out that the correlation was only for genre. In this way, male preferential features were significant in filters, while female preferential features were frequent in dairies. In a recent study on gender, Tse and Hyland (2008) analyzed a corpus of academic book reviews written by male and female writers and also interviews with academics from both philosophy and biology fields. They found that the interactional kind of metadiscourse was used twice the interactive one by both genders, especially by male writers and accordingly showed the evaluative nature of this genre. Male writers made more use of 'engagement markers', 'hedges', 'boosters', and 'self mentions'; Interviews with academics also confirmed this. Considering interactive features, female writers made more use of transitions which was the second significant feature in male writers' texts. This can be a proof for both genders' tendency in making the argument clear for readers. Female writers were heavy users of evidential markers, confirmed by academics interviews, but there was no significant difference between them in the use of code glosses. In sum, according to the genre (spoken or written) and community of practices in which genres happen, both genders make different uses of metadiscourse features.

\section{Procedure and the Corpus}

The purpose of the current study was to investigate whether male and female writers utilize metadiscoursal resources differently or similarly in the four sections of research articles. To fulfil this purpose, the intended corpus including 32 Empirical/Experimental Applied Linguistics RAs, published between 2005 and 2011, were categorized into two groups: Female and Male writers' articles: 16 articles belonged to Female writers and 16 articles belonged to Male writers (see Appendixes 1 and 2 for complete bibliography of articles).

\subsection{Selection Process of the Journals and the Articles}

Two criteria were involved in choosing the intended journals: their rating among Applied Linguistics (AL) lecturers and their accessibility to the most important publications. During this process, ten lecturers holding PhD in AL were individually interviewed - this is known as informant nomination- (see Hyland 2000, 2002, 2007). They were asked to name and rank the five most prestigious international journals defined as journals with higher degree of popularity and reputation among academics which they would want/wish their research articles to be published in. Then the responses were scored and the journals were ranked based on their score (Kuhi et al., 2012). An important question at this point, however, might be to ask if writer's nationality (native or non-native) can affect the study. According to Lindeberg's (2004) view top English-medium journals severity in review processing and also their demands according to their specific guidelines "make it irrelevant whether the RAs were written by native English speakers or not" (p. 8). The highest-ranked journals were found to be as follows:

1. TESOL Quarterly (Teachers of English to Speakers of Other Languages Quarterly Journal)

2. AL Journal (Applied Linguistics Journal)

3. ESP Journal (English for Specific Purposes Journal)

4. Journal of Pragmatics

5. System Journal 
At the next stage, to observe random sampling procedure, all articles of the five above mentioned journals published within the specified period (2005-2011) were listed. The number of the listed articles in each journal differed due to the variety in the publication frequency of the journals. The corpus, therefore, comprised of 32 articles, including 8 from Applied Linguistics, 7 from TESOL Quarterly, 7 from System, 6 from ESP, and 4 from Pragmatics.

As the focus of this study was on the four different sections of applied linguistics RAs, namely, Introduction, Methodology, Results and Discussion/Conclusion (IMRD/C), the reference sections, tables, abstracts, figures, bibliographies, footnotes, direct quatations of other researchers and headings were excluded from the domian of the present study, so forming an electronic corpus of totalling 221, 284 words out of the four sections of the 32 articles. Moreover, considering the fact that different sections of articles perform different rhetorical functions realized through applying different linguistic resources (e.g., Salager-Meyer, 1994; Hopkins and Dudly-Evans, 1988; Adams-Smith, 1984), those articles with separate results and discussion/conclusion sections were chosen.

\subsection{Data Analysis Procedure}

In order to achieve an acceptable degree of reliability in the data analysis procedure, two processes of researchers' rating and inter-rater analysis along with consultation with one specialist in the intended field were applied in the present study. First, the four different sections of 32 RAs, regarding Hyland's (2005a) framework of metadiscourse resources and Halliday's functional approch, were read carefully by the researchers to identify both interactive and interactional metadiscourse resources. In order to increase the crediblity of the ratings, at the second stage of data analysis, an outside specialist in TEFL who had expertise on metadicourse, selected one page from each article randomly, and rated them seperately and the average counts were allocated to each element of discourse. The researchers made use of frequency counts to analyze the data in the study. Frequency counts (the below formula) was used to show the frquency of different interpersonal metadiscoursal categories as found in the four different sections of RAs produced by male and female writers.

$$
\text { F per } 1,000 \mathrm{~W}=\frac{\text { Interactive/Interactional MRe belonging to each cate gory in } \mathrm{I} / \mathrm{M} / \mathrm{R} / \mathrm{D}}{\text { the total number of words } \mathrm{in} I / M / R / D} \times 1,000
$$

Also, the researchers took advantage of percentage figures by means of the following formula (Hyland, 2005a) to show the distribution of each metadiscourse item between sections and also between groups.

$$
\text { Percent }=\frac{\text { Interactive/Interactional MRs belonging to each category in } 1 / \mathrm{M} / \mathrm{R} / \mathrm{D}}{\text { the total number of categories in } 1 / M / R / D} \times 100
$$

Chi-Square with a significance of $p$-value $=0.05$ by means of SPSS (versian 14) was applied in the current study.

\section{Results}

\subsection{Distribution of Interpersonal Metadiscourse Resources in Introduction Section of Male and Female Writers' Articles}

Introduction section of both male and female writer's articles were analysed to characterize difference between two groups of writers in terms of interpersonal metadiscourse resources. Here, the frequency of interpersonal metadiscourse resources was calculated per 1,000 words and analysed by Chi-square tests. As it can be seen in Table 2, the total frequency of interpersonal metadiscourse resources in Introduction section of male and females writers' articles were 96.43 per 1,000 words (Interactive 61.91, Interactional 34.52) and 99.27 per 1,000 words (Interactive 62.81, Interactional 36.46) respectively. This finding along with Chi-square tests confirmed that there was not any significant difference between male and female writers' use of metadiscourse elements.

Table 2. Frequency of Interpersonal Metadiscourse Resources in Introduction Section of Male and Female Writers

\begin{tabular}{lcc}
\hline & Applied Linguistics RAs' Introduction section & Male \\
\hline Total words & Female & 30590 \\
Total devices of Interactive & 28195 & 1894 \\
F per1,000words & 1771 & 61.91 \\
Total devices of Interactional & 62.81 & 1056 \\
F per 1,000words & 1028 & 34.52 \\
Totals & 36.46 & 96.43 \\
\hline
\end{tabular}

Note: $F=$ Frequency; RAs=Research Articles

Chi-Square Test (Interactive features): Chi-Square $=1.08, \mathrm{DF}=4, \mathrm{p}$-value $=0.89$

Chi-Square Test (Interactional features): Chi-Square $=0.26, \mathrm{DF}=4$, exact $\mathrm{p}$-value $=0.99$ 
According to table 3, 'Evidentials' were the most frequent interactive resources with 'Transitions', 'Code glosses', and 'Frame markers' and 'Endophorics' following next. Considering interactional subcategories, 'Hedges' were the most frequent interactional resources with 'Attitudes', 'Boosters', 'Engagement' and 'Self mentions' coming next.

Table 3. Categorical Distribution in Introduction Section of Articles Written by Male and Female Writers

\begin{tabular}{|c|c|c|c|c|c|c|c|}
\hline \multirow[t]{2}{*}{ Gender } & \multirow{2}{*}{$\frac{\text { Female }}{\mathrm{F}}$} & \multicolumn{5}{|c|}{ Male } & \multirow[b]{2}{*}{$\mathrm{F} / \mathrm{M} \pm$} \\
\hline & & $\mathrm{P}$ & Raw number & $\mathrm{F}$ & $\mathrm{P}$ & Raw number & \\
\hline Evidentials & 25.0 & 39.80 & 705 & 28.6 & 46.25 & 876 & -3.6 \\
\hline Transitions & 15.3 & 24.50 & 434 & 13.3 & 21.54 & 408 & 2 \\
\hline Code glosses & 12.6 & 20.15 & 357 & 11.3 & 18.32 & 347 & 1.3 \\
\hline Frame markers & 7.5 & 12.25 & 214 & 5.6 & 9.13 & 173 & 1.9 \\
\hline Endophorics & 2.1 & 3.44 & 61 & 2.94 & 4.75 & 90 & -0.8 \\
\hline Total Interactive & 62.8 & 100 & 1771 & 61.9 & 100 & 1894 & 0.9 \\
\hline Hedges & 16.9 & 46.59 & 479 & 18.2 & 52.65 & 556 & 1.3 \\
\hline Attitude markers & 12.0 & 32.97 & 339 & 9.6 & 27.93 & 295 & 2.4 \\
\hline Boosters & 5.4 & 15.07 & 155 & 4.3 & 12.5 & 132 & 1.1 \\
\hline Engagements & 1.6 & 4.57 & 47 & 2.1 & 6.34 & 67 & -0.5 \\
\hline Self-mentions & 0.2 & 0.77 & 8 & 0.1 & 0.56 & 6 & 0.1 \\
\hline Total Interactional & 36.4 & 100 & 1028 & 34.5 & 100 & 1056 & 1.9 \\
\hline Overall & 99.27 & 100 & 2799 & 96.43 & 100 & 2950 & 2.84 \\
\hline
\end{tabular}

Note: $\mathrm{F}=$ Frequency; $\mathrm{P}=$ Percent

\subsection{Distribution of Interpersonal Metadiscourse Resources in Method Section of Male and Female Writers' Articles}

As Table 4 displays, male writers used higher frequency of interactive devices (42.73 per 1,000 words) than female writers ( 37.03 per 1,000 words) in this section. But, from interactional perspective, female writers utilized almost more frequency (27.19 per 1, 000 words) than male writers ( 22.11 per 1,000 words). Accordingly, the overall frequency of interpersonal features was the same in method section of both male and female writers' articles (i.e. 64.85 and 64.22, respectively) and the results of Chi- square test at $\alpha=0.05$ with degrees of freedom of $4(\mathrm{DF}=4)$ indicated that differences between male and female writers in the use of both interactive and interactional metadiscourse resources were not statistically significant.

Table 4. Frequency of Interpersonal Metadiscourse Resources in Method Section of Male and Female Writers' Articles

\begin{tabular}{lcc}
\hline & Applied Linguistics RAs' Method section & \\
\hline & Female & Male \\
\hline Total words & 21548 & 20663 \\
Total Interactive devices & 798 & 883 \\
F per1,000words & 37.03 & 42.73 \\
Total Interactional devices & 586 & 457 \\
F per 1,000words & 27.19 & 22.11 \\
Totals & 64.22 & 64.85 \\
\hline
\end{tabular}

Chi-Square Test (Interactive features): Chi-Square $=0.35, \mathrm{DF}=4, \mathrm{p}$-value $=0.98$

Chi-Square Test (Interactional features): Chi-Square $=0.28, \mathrm{DF}=4$, exact $\mathrm{p}$-value $=0.99$

'Transitions' along with 'Frame markers', 'Evidentials', 'Code glosses' and 'Endophorics' in male group and 'Code glosses', 'Frame markers', 'Evidentials' and 'Endophorics' in female group were the most frequent interactive metadiscourse elements. And with regard to interactional subcategories 'Hedges' were the most frequent interactional metadiscourse with 'Attitude', 'self mentions', 'boosters', and 'engagements' being the second, third, fourth and fifth (see Table 5). 
Table 5. Categorical Distribution in Method Section of Articles Written by Male and Female Writers

\begin{tabular}{lccccccc}
\hline \multirow{1}{*}{ Gender } & Female & \multicolumn{7}{c}{ Male } & \\
\cline { 2 - 6 } & $\mathrm{F}$ & $\mathrm{P}$ & Raw number & $\mathrm{F}$ & $\mathrm{P}$ & Raw number & \pm \\
\hline Transitions & 10.53 & 28.44 & 227 & 12.97 & 30.35 & 268 & $\mathbf{- 2 . 4 4}$ \\
Code glosses & 7.88 & 21.30 & 170 & 7.11 & 16.64 & 147 & 0.77 \\
Frame markers & 6.82 & 18.42 & 147 & 8.95 & 20.95 & 185 & $\mathbf{2 . 1 3}$ \\
Evidentials & 6.82 & 18.42 & 147 & 8.37 & 19.59 & 173 & 1.55 \\
Endophorics & 5.01 & 13.53 & 108 & 5.32 & 12.45 & 110 & -0.31 \\
Total Interactive & 37.03 & 100 & 798 & 42.73 & 100 & 883 & -5.7 \\
Hedges & 10.76 & 39.59 & 232 & 9.63 & 43.54 & 199 & 1.13 \\
Attitude markers & 7.42 & 27.30 & 160 & 5.85 & 26.47 & 121 & 1.57 \\
Self-mentions & 4.26 & 15.69 & 92 & 2.75 & 12.47 & 57 & 1.51 \\
Boosters & 3.01 & 11.09 & 65 & 2.61 & 11.81 & 54 & -0.4 \\
Engagements & 1.71 & 6.31 & 37 & 1.25 & 5.68 & 26 & 0.46 \\
Total Interactional & 27.19 & 100 & 586 & 22.11 & 100 & 457 & 5.08 \\
Overall & 64.22 & 100 & 1384 & 64.85 & 100 & 1340 & -0.63 \\
\hline
\end{tabular}

Note: $\mathrm{F}=$ Frequency; $\mathrm{P}=$ Percent

\subsection{Distribution of Interpersonal Metadiscourse Resources in Results Section of male and female Writers}

Turning to the distribution of interpersonal features in the Results section, considerably fewer interpersonal signals were found; the male writers employed approximately more of almost two categories, namely interactive and interactional; and the cross-gender differences were more significantly marked.

Table 6. Frequency of Interpersonal Metadiscourse Resources in Results section of Male and Female Writers

\begin{tabular}{lcc}
\hline & Applied Linguistics RAs' Results section & \\
\hline & Female & Male \\
Total words & 35965 & 26970 \\
Total devices of Interactive & 885 & 877 \\
F per1,000words & 24.60 & 32.51 \\
Total devices of Interactional & 962 & 941 \\
F per 1,000words & 26.74 & 34.89 \\
Totals & 51.35 & 67.40 \\
\hline
\end{tabular}

Chi-Square Test (Interactive features): Chi-Square $=1.46, \mathrm{DF}=4, \mathrm{p}$-value $=0.83$

Chi-Square Test (Interactional features): Chi-Square $=0.99, \mathrm{DF}=4$, exact $\mathrm{p}$-value $=0.91$

The frequencies of overall interpersonal metadiscourse resources were computed per 1,000 words in applied linguistics RAs of male and female writers. As it is shown in the Table 6, the total frequency of interactive metadiscourse resources for males was 32.41 per 1,000 words while it was 24.60 per 1,000 words for females; similarly, in the case of interactional metadiscourse resources, male group used more of them with a frequency of 34.89 per 1,000 words, whereas it was 26.74 for female writers. The results were found similar to what was found in previous sections; the results of the Chi- square test at $\alpha=0.05$ with degrees of freedom of $4(\mathrm{DF}=4)$ indicated that differences between male and female writers in the use of both interactive and interactional metadiscourse resources weren't statistically different.

Regarding subcategories, 'Transitions' were the most frequent interactive metadiscourse in both groups, followed by 'Code glosses', 'Frame markers', 'Endophorics' and 'Evidential' in females' writings and 'Endophorics', 'Code glosses', 'Frame markers' and 'Evidentials' in males'. 
Table 7. Categorical Distribution in Results Section of Articles Written by Male and Female Writers

\begin{tabular}{|c|c|c|c|c|c|c|c|}
\hline \multirow[t]{2}{*}{ Gender } & \multicolumn{3}{|c|}{ Female } & \multicolumn{3}{|c|}{ Male } & \multirow[b]{2}{*}{$\pm \mathrm{F} / \mathrm{M}$} \\
\hline & $\mathrm{F}$ & $P$ & Raw number & $\mathrm{F}$ & $\mathrm{P}$ & Raw number & \\
\hline Transitions & 9.48 & 38.53 & 341 & 11.79 & 36.25 & 318 & -2.31 \\
\hline Code glosses & 6.14 & 24.97 & 221 & 5.85 & 18.01 & 158 & 0.29 \\
\hline Frame markers & 3.36 & 13.67 & 121 & 5.04 & 15.50 & 136 & -1.68 \\
\hline Endophorics & 3.22 & 13.10 & 116 & 8.23 & 25.31 & 222 & -5.01 \\
\hline Evidentials & 2.39 & 9.71 & 86 & 1.59 & 4.90 & 43 & -0.8 \\
\hline Total Interactive & 24.60 & 100 & 885 & 32.51 & 100 & 877 & -7.91 \\
\hline Hedges & 9.87 & 36.90 & 355 & 15.94 & 45.69 & 430 & -6.07 \\
\hline Attitude markers & 10.37 & 38.77 & 373 & 11.90 & 34.11 & 321 & -1.53 \\
\hline Boosters & 4.64 & 17.35 & 167 & 3.85 & 11.05 & 104 & 0.79 \\
\hline Engagement markers & 1.30 & 4.88 & 47 & 2.26 & 6.48 & 61 & -0.96 \\
\hline Self-mentions & 0.55 & 2.07 & 20 & 0.92 & 2.65 & 25 & -0.37 \\
\hline Total Interactional & 26.74 & 100 & 962 & 34.89 & 100 & 941 & -8.15 \\
\hline Overall & 51.35 & 100 & 1847 & 67.40 & 100 & 1818 & 16.05 \\
\hline
\end{tabular}

Note: $\mathrm{F}=$ Frequency; $\mathrm{P}=$ Percent

\subsection{Distribution of Interpersonal Metadiscourse Resources in Discussion/Conclusion Section of Male and Female Writers' Article}

As it can be seen in Table 8, the total frequency of interpersonal metadiscourse resources in discussion/conclusion section of male and female writers' research articles was 89.44 and 78.48 per 1,000 words, respectively. It suggested that there is no considerable difference between male and female writers.

Table 8. Frequency of Interpersonal Metadiscourse Resources in Discussion/ Conclusion Section of Male and Female writers' article

\begin{tabular}{lcc}
\hline Applied Linguistics RAs' Discussion/Conclusion section & & \\
\hline & Female & Male \\
\hline Total words & 29693 & 27660 \\
Total devices of Interactive & 1194 & 999 \\
F per1,000words & 40.21 & 36.11 \\
Total devices of Interactional & 1459 & 1172 \\
F per 1,000words & 49.13 & 42.37 \\
Totals & 89.44 & 78.48 \\
\hline
\end{tabular}

Chi-Square Test (Interactive features): Chi-Square $=0.92, \mathrm{DF}=4, \mathrm{p}$-value $=0.92$

Chi-Square Test (Interactional features): Chi-Square $=1.20, \mathrm{DF}=4$, exact $\mathrm{p}$-value $=0.88$

Again, the results of the Chi-square test at $\alpha=0.05$ with degrees of freedom of $4(\mathrm{DF}=4)$ indicated that differences between two groups under study in the use of both interactive and interactional metadiscourse resources weren't statistically different. 
Table 9. Categorical Distribution in Discussion/Conclusion Section of Articles Written by Male and Female Writers

\begin{tabular}{lccccccc}
\hline \multicolumn{1}{c}{ Gender } & Female & \multicolumn{5}{c}{ Male } & \\
\cline { 2 - 6 } & $\mathrm{F}$ & $\mathrm{P}$ & Raw number & $\mathrm{F}$ & $\mathrm{P}$ & Raw number & $\pm \mathrm{F} / \mathrm{M}$ \\
\hline Transitions & 16.19 & 40.28 & 481 & 14.64 & 40.54 & 405 & 1.55 \\
Evidentials & 8.11 & 20.18 & 241 & 9.54 & 26.42 & 264 & -1.43 \\
Code glosses & 7.98 & 19.84 & 237 & 5.63 & 15.61 & 156 & $\mathbf{2 . 3 5}$ \\
Frame markers & 5.32 & 13.23 & 158 & 3.43 & 9.50 & 95 & 1.89 \\
Endophorics & 2.59 & 6.44 & 77 & 2.85 & 7.90 & 110 & 0.26 \\
Total Interactive & 40.21 & 100 & 1194 & 36.11 & 100 & 999 & 4.1 \\
Hedges & 21.89 & 44.55 & 650 & 23.21 & 54.77 & 642 & -1.32 \\
Attitude markers & 16.40 & 33.37 & 487 & 9.94 & 23.46 & 275 & $\mathbf{6 . 4 6}$ \\
Boosters & 6.56 & 13.36 & 195 & 5.38 & 12.71 & 149 & 1.18 \\
Engagements & 2.92 & 5.96 & 87 & 3.03 & 7.16 & 84 & -0.11 \\
Self-mentions & 1.34 & 2.74 & 40 & 0.79 & 1.87 & 22 & 0.55 \\
Total Interactional & 49.13 & 100 & 1459 & 42.37 & 100 & 1172 & 6.76 \\
Overall & 89.44 & 100 & 2653 & 64.85 & 100 & 2171 & 24.59 \\
& & & & & & &
\end{tabular}

Note: $\mathrm{F}=$ Frequency; $\mathrm{P}=$ Percent

Here, 'Transitions' were the most frequent interactive metadiscourse with 'Evidentials', 'Code glosses', 'Frame markers', 'Endophorics' being the second, third, fourth and fifth frequent subcategories. Regarding interactional subcategories, 'Hedges' were the most frequent interactional metadiscourse and 'Attitudes', 'Boosters', 'Engagements' and 'Self mention' stood next.

\section{Discussion and Conclusions}

\subsection{Metadiscourse and Introduction Section of Male/Female Writers' Articles}

As the results of the current study showed, male and female writers of applied linguistics research articles, tended to use much more metadiscourse in the introduction section of their articles. In this way, writers appealed to background knowledge by the inclusion of evidentials, and also to their authoritative and negative affective stance by means of hedges and attitude markers, respectively. Interestingly female writers used more attitude markers, while male writers tended to use more evidential. Tse and Hyland (2008) relate the two different genders' preferences for different interactive and interactional devices "to very different ways of conceptualizing and argumentation and setting out ideas in a persuasive way" (p. 1242). One possible explanation for the frequent use of evidentials by male writers can be their interest in reviewing items of previous research which helps them to establish a territory as a third step of first move in their articles. But, this was not in line with D'Angelo's (2008) study in which female writers utilized a higher number of evidentials than their male colleagues. The discrepancies not only stem from gender differences, but generally rooted in the individual styles of two groups or even ideational content.

On the other hand, female writers' greater willingness to make their discourse affective might be the result of their emotional or sentimental nature. It might be speculated that the greater use of adjectives as attitude markers can make the discourse interesting for readers so as to show the importance of their work. An interpretation is that female writers tended to be more concerned about paying attention to evaluation of discourse by means of attitudinal lexis. Generally, both male and female writers organized their texts in a similar way. So, it can be a support for Francis et al.'s (2001) and Tse and Hyland's (2008) claim that the academic writing of both male and female writers shows more similarities than differences. But, Holmes' (1984) claim on the preference of female speakers in using metadiscoursal elements couldn't be in line with what was found in this study. This disagreement can be justified by the genre, which two different genres of spoken and written may not be the same in this case.

\subsection{Metadiscourse and Method Section of Male/Female Writers' Articles}

Here, in the process of gathering and analysing the data in a more meaningful way for readers, it seems that male authors have paid more attention. According to Tse \& Hyland (2008) this makes the process of informing the readers of the process of work more manageable and also 'reader friendliness' (p.1242). In contrast, greater use of interactional devices by female writers can be a proof for different style of writing in the method section. Higher frequency of attitude markers (through different meanings of surprise, agreement, importance, and frustration) and self mentions can be considered as writer's confidence about their commitment. Hyland (2001) attributed the use of 'self mentions', by means of first person pronouns and possessive adjectives, by research article authors to their intention to be closely associated with their work or to mediate in the relationship between their arguments and their discourse communities. 
One explanation is that making author's presence noticed in any written academic discourse gives a writer a community-approved persona and consolidates her credibility among other practitioners and community members. These findings went for the findings obtained in Tse and Hyland (2008). According to Tse and Hyland (2008), females made slightly more use of self-mention and attitudinal markers. So, here it can be concluded that attitudinal markers are the most-sizable inter-gender difference.

\subsection{Metadiscourse and Results Section of Male/Female Writers'Articles}

Turning to the distributions of interpersonal resources in results section of male and female writers' articles, it was found that the overall frequency of interpersonal resources for female group was considerably low. It seems that male writers paid much more attention to how they projected themselves into their texts than female writers by transitions, endophorics, and hedges.

Considering the significant differences that were found between male writers and their counterparts in the use of hedges, one might argue that the use of this subcategory is gender-specific rather than discipline-specific. That is to say authors' gender constrains and conditions the use of hedges in realizing the results section of the articles. So the results of the present section supported Crismore et al. (1993) as well as McMillan et al.'s (1977) study. They attributed this overuse of hedging devices on the part of male writers to show more interest in uncertainty and writer-reader interaction. But it went against Tse and Hyland (2008) who found no difference in the use of hedges. It is not also in accordance with Lakoff's (1975) theory about female writer's tendency of using hedges. According to Lakoff, hedges show low statues of women and also the social pressure to talk like a lady. Lakoff's theory can't be true for the corpus of this study because of two reasons. Although her theory was very influential in the history of language and gender studies and considered as the first theory, but it can't be true to generalize about the present study. Firstly, the genre under study was everyday conversation especially in the use of pragmatic particles including I think, you know, and sort of in that of Lakoff's study and secondly, according to Dubios and Crouch (1975), she intrudes her personal observation in making these ground-breaking ideas. According to them, her observation is based on a highly skewed and nonrandom sample of people.

\subsection{Metadiscourse and Discussion/Conclusion Section of Male/Female Writers' Articles}

Male and female writers show almost similarity in the use of interactional devices in the Discussion section except in the case of attitude markers. The use of attitudinal devices happened to be higher in female writers' articles as they were generally considered to be sentimental or emotional in contrast with male writers. Female writers also appeared to give a higher priority to glossing wherever they felt that the reader might be burdened with unfamiliar terms or they might not have enough literacy to grasp what the writer intended to get across. In this way, they tried to make themselves as a friend to readers and also to be as an assistant for them in making clear the interpretations of discussion section by rephrasing, exemplifying the obtained arguments/results again. Therefore, here, the use of attitudes and code glosses seem to be governed by the author's gender since, other things being equal, female writers displayed different rhetorical patterns of use regarding these two subcategories. The results of the present study in the Discussion/Conclusion section of the corpora regarding code glosses ran against that of Tse and Hyland's (2008) study. They found that male and female writers showed the same pattern of use in regard to this category. But unlike code glosses regarding attitude markers and females' priority can be a support for Lakoff's (1975) theory that women's more use of empty adjectives can be associated with their emotions and feelings. She also relates it to their nature as women. It can be concluded about attitude markers and different sections of articles that gender is better practiced and revealed through the use of this subcategory.

Finally, the most evident and interesting point in this study, was the neutral nature of boosters, or items used for reinforcing arguments and expressing conviction, in all the four sections of articles. It was against the findings of Crismore et al. (1993), Francis et al. (2001) and also Tse and Hyland (2008) who observed male preference for more certainty markers and more confident style. They attributed it to male's dominant and higher status in academic writing as well as supporting their confidence in a judgment. It also went against the findings of Johnson and Roen (1992) and Herbert (1990). They found female writers priority in the application of Boosters. These differences in the literature about the priority of men or even female in the application of this subcategory of metadiscourse can be attributed to different genres (especially sub-genres including Introduction-Method-Results and Discussion/Conclusion) and discourse communities under the study which can influence the use of metadiscourse. But it can be a support for the findings of Lynch and Strauss-Noll (1987), Rubin and Greene (1992) who found little difference in the use of assertion in the written argument patterns of male and female students.

In the current study, the analysis of research articles written by two groups of males and females revealed that the author's gender doesn't seem to influence the frequency of used markers. Following what Tse and Hyland (2008), D'Angelo (2008), Francis et al. (2001) concluded, the overall use of metadiscoursal elements in soft disciplines appears to be more discipline-specific than gender-based; that the academic writing of men and women exhibits far more similarities than differences. Seemingly, author's gender cannot be a determining factor in the incorporation of metadiscourse elements into a written discourse. It can be concluded that writers' awareness of the metadiscourse in different rhetorical sections - along with their awareness of the needs of a discipline when writing in specific disciplineprevent them from misunderstandings and makes the road smoothly for them to follow the conventions of academic discourse in which they are writing. Knowledge of such cross sectional differences is important not only for researchers but also for novice students who are trying to acquire the appropriate academic knowledge. In other words, it is the purpose in each section which determines the frequency of linguistic features (metadiscourse features), for example, in 
the method section the purpose is to be descriptive, while in the discussion section it is to be argumentative. Interestingly, no significant difference was found between male and female writers in their endeavour for both organizing and evaluating the discourse.

\section{Acknowledgements}

This paper is part of my thesis. Therefore, I would like to express my deepest gratitude to Dr. Davud Kuhi, my supervisor, for his consistent efforts and true desire to keep me on track in the process of MA thesis.

\section{References}

Adams Smith, D.E. (1984). Medical discourse: Aspects of author's comment. English for Specific Purposes, 3, $25-36$. Crismore, A. (1983). Metadiscourse: What it is and how it is used in school and non-school social science texts. University of Illinois: Centre for the Study of Reading. Technical Report 273.

Crismore, A. (1989). Talking with readers: Metadiscourse as rhetorical act. New York: Peter Lang.

Crismore, A. (2004). Pronouns and metadiscourse as interpersonal rhetorical devices in fundraising letters: A corpus linguistic analysis. In U. Connor \& T. A. Upton (Eds.), Discourse in the professions: Perspectives from corpus linguistics (pp. 307-330). Amsterdam: John Benjamins.

Crismore, A. \& Farnsworth, R. (1990). Metadiscourse in popular and professional science discourse. In W. Nash (Ed.), The Writing Scholar: Studies in Academic Discourse (pp. 118-136). Newbury Park, CA: SAGE.

Crismore, A., Markkanen, R., Steffensen, M.S., (1993). Metadiscourse in persuasive writing: A study of texts written by American and Finnish University students. Written Communication, 10(1), 39-7.

D'Angelo, L. (2008). Gender identity and authority in academic book reviews: A metadiscourse analysis across disciplines. Linguistica e Filologia, 27, 205-221.

Dubois, B. L., \& Crouch, I. (1975). The question of tag question in women's speech: They don't really use more of them, do they? Language in Society, 4, 289-294.

Eggins, S. (2004). An introduction to systemic functional linguistics. London, England: Continuum.

Francis, B., Robson, J. \& Read, B. (2001). An analysis of undergraduate writing styles in the context of gender and achievement. Studies in Higher Education, 26(3), 313-326.

Grey, C. (1998). Towards an overview on gender and language variation. Retrieved November 21, 2006, from http://www.eche.ac.uk/study/schsubj/human/English/rh/modules/337-1.htm

Harris, Z. (1959). The transformational model of language structure. Anthropological Linguistics, 1(1), $27-29$.

Herbert, R. K. (1990). Gender differences in compliment behaviour. Language in Society, 19, 201-224.

Hernandez Guerra, C., \& Hernandez Guerra, J. M. (2008). Discourse analysis and pragmatic metadiscourse in four subareas of Economics research articles. Iberica, 16, 81-108.

Herring, S. C. \& Paolillo, J. C. (2006). Gender and genre variation in weblogs. Journal of Sociolinguistics, 10(4): 439459.

Holmes, J. (1984). Women's Language: A Functional Approach. General Linguistics, 24(3), 149-178.

Holmes, J. (1988). Paying compliments: A sex-preferential positive politeness strategy. Journal of Pragmatics, 12(3), $445-465$.

Holmes, J. (1989). Sex differences and apologies: One aspect of communicative competence. Applied Linguistics, 10(2), 194-213.

Hopkins, A., \& Dudley-Evans, T. (1988). A genre-based investigation of the discussion sections in articles and dissertations. English for Specific Purposes, 7(1), 113-121.

Hyland, K. (1994). Hedging in academic writing and EAP textbooks. English for Specific Purposes, 13(3), $239-256$.

Hyland, K. (1998). Persuasion and context: the pragmatics of academic metadiscourse. Journal of Pragmatics, $30,437-$ 55.

Hyland, K. (2000). Disciplinary discourses: Social interactions in academic writing. Harlow, Essex: Pearson Education.

Hyland, K. (2001). Humble servants of the discipline? Self-mention in research articles. English for Specific Purposes, 20(3), 207-226.

Hyland, K. (2002). Authority and invisibility: Authorial identity in academic writing. Journal of Pragmatics, 34(8), 1091-1112.

Hyland, K. (2005a). Metadiscourse: Exploring interaction in writing. London: Continuum.

Hyland, K. (2005b). Stance and engagement: A model of interaction in academic discourse. Discourse Studies, 7(2), 173-191.

Hyland, K. (2007). Applying a gloss: Exemplifying and reformulating in academic discourse. Applied Linguistics, 28(2), 266-285.

Hyland, K., \& Tse, P. (2004). Metadiscourse in academic writing: a reappraisal. Applied Linguistics 25(2), $156-177$.

Janssen, A., \& Murachver, T. (2004). The relationship between gender and topic in gender-preferential language use. Written Communication, 21(4), 344-367.

Johnson, D., \& D. H. Roen. (1992). Complimenting and involvement in peer-reviews: Gender variation. Language in society, 21(1), 27-57. 
Kuhi, D. Yavari, M. \& Sorayaeiazar, A. (2012). Metadiscourse in applied linguistics research articles: A cross-sectional survey. Mediterranean Journal of Social Sciences, 3(11), 405-414.

Lakoff, R. (1975). Language and women's place. New York: Harper \& Row.

Lautamatti, L. (1978). Observations on the development of the topic in simplified discourse. In V. Kohonen \& N. E. Enkvist (Eds.), Text linguistics, cognitive learning, and language teaching (pp. 71-104). Turku, Finland: Finnish Association for Applied Linguistics.

Lyons, J. (1977). Semantics. (Vols. 1 \& 2). Cambridge: CUP.

Lynch, C., \& Strauss-Noll, M. (1987). Mauve Washers: Sex-differences in freshman writing. English Journal, 76, 9094.

McMillan, J., Clifton, R., Mcgrath, D., \& Gale, W.S. (1977). Women's language: Uncertainty or interpersonal sensitivity and emotionality?. Sex Roles, 3, 545-559.

Rubin, D. L., \& Greene, K. (1992). Gender typical style in written language. Research in the Teaching of English, 26, 7-40.

Salager-Meyer, F. (1994). Hedges and textual communicative function in medical English written discourse. English for Specific Purposes, 13(2), 149-170.

Schiffrin, D. (1980). Metatalk: Organisational and evaluative brackets in discourse. Language and Social Interaction, $50,199-236$.

Swales, J. (1990). Genre analysis: English in academic and research setting. Cambridge: Cambridge University Press. Tannen, D. (1994). Gender and Discourse. Oxford: Oxford University Press.

Tse, p., \& Hyland, K. (2008). Robot Kung Fu: Gender and professional identity in biology and philosophy reviews. Journal of Pragmatics, 40, 1232-1248.

Vande Kopple, W. (1985). Some exploratory discourse on metadiscourse. College Composition and Communication, 36, 82-93.

Williams, J. M. (1981). Style: Ten lessons in clarity and grace. Chicago: University of Chicago Press.

\section{Appendix 1}

\section{List of Female Writer's Articles}

\begin{tabular}{|c|c|}
\hline No. & Article \\
\hline 1 & $\begin{array}{l}\text { Pulido, D. (2007). The effects of topic familiarity and passage sight vocabulary on L2 lexical inferencing and } \\
\text { retention through reading. Applied Linguistics, 28(1), 66-86. }\end{array}$ \\
\hline 2 & $\begin{array}{l}\text { Larsen-Freeman, D. (2006). The emergence of complexity, fluency, and accuracy in the oral and written } \\
\text { production of five Chineses learners of English. Applied Linguistics, 27, 590-619. }\end{array}$ \\
\hline 3 & $\begin{array}{l}\text { North, S. (2005). Disciplinary Variation in the Use of Theme in Undergraduate Essays. Applied Linguistics, } \\
26(3), 431-452 .\end{array}$ \\
\hline 4 & $\begin{array}{l}\text { Yiakoumetti, A. (2006). A bidialectal programme for the learning of Standard Modern Greek in Cyprus. Applied } \\
\text { Linguistics, 27, 295-317. }\end{array}$ \\
\hline 5 & $\begin{array}{l}\text { Mcdowell, H. \& Lorch, M.P. (2008). Phonemic awareness in Chinese L1 readers of English: Not simply an effect } \\
\text { of orthography. TESOL Quarterly, 42(3), 495-512. }\end{array}$ \\
\hline 6 & Setter, J. (2006). "Speech rhythm in world Englishes. The case of Hong Kong". TESOL Quarterly, 40, 763-782. \\
\hline 7 & $\begin{array}{l}\text { Li, Y. (2007). Apprentice Scholarly Writing in a Community of Practice: An Interview of an NNES Graduate } \\
\text { student writing a research article. TESOL Quarterly, } 41,55-79 \text {. }\end{array}$ \\
\hline 8 & $\begin{array}{l}\text { Winke, P. (2011). Evaluating the validity of a high-stakes ESL test: Why teachers' perceptions matter. TESOL } \\
\text { Quarterly, } 45(4), 628-660 .\end{array}$ \\
\hline 9 & $\begin{array}{l}\text { Zareva, A. (2005). Models of lexical knowledge assessment of second language learners of English at higher } \\
\text { levels of language proficiency. System, 33(4), 547-562. }\end{array}$ \\
\hline 10 & $\begin{array}{l}\text { Shen, Helen H. (2005). An investigation of Chinese-character learning strategies among non-native speakers of } \\
\text { Chinese. System, 33, 49-68. }\end{array}$ \\
\hline 11 & Diab, R. L. (2006).University students' beliefs about learning English and French in Lebanon, System, 34, 80-96. \\
\hline 12 & $\begin{array}{l}\text { Sesek, U. (2007). English for teachers of EFL-Toward a holistic description. English for Specific Purposes, 26, } \\
\text { 411-425. }\end{array}$ \\
\hline 13 & $\begin{array}{l}\text { McGrath, L., \& Kuteeva, M. (2011). Stance and engagement in pure mathematics research articles: Linking } \\
\text { discourse features to disciplinary practices. English for Specific Purposes, xxx, 1-13. }\end{array}$ \\
\hline 14 & $\begin{array}{l}\text { Kaewpet, Ch. (2009). Communication needs of Thai civil engineering students, English for Specific Purposes, } \\
28,266-278 .\end{array}$ \\
\hline 15 & $\begin{array}{l}\text { Dafouz-Milne E. (2008): "The pragmatic role of textual and interpersonal metadiscourse markers in the } \\
\text { construction and attainment of persuasion: A cross-linguistic study of newspaper discourse". Journal of } \\
\text { Pragmatics, } 40,95-113 \text {. }\end{array}$ \\
\hline 16 & Adel, A. (2011). Rapport building in student group work. Journal of Pragmatics, 43, 2932-2947. \\
\hline
\end{tabular}




\section{Appendix 2}

\section{List of Male Writer's Articles}

\begin{tabular}{|c|c|}
\hline No. & Article \\
\hline 1 & $\begin{array}{l}\text { Mackey, A. (2006). Feedback, noticing and instructed second language learning. Applied linguistics, 27/3, } \\
405-430 .\end{array}$ \\
\hline 2 & Alderson, Ch. (2007). Judging the frequency of English words. Applied Linguistics, 28/3, 383-409. \\
\hline 3 & $\begin{array}{l}\text { Vandergrift, L. (2005). Relationships among motivation orientations, metacognition awareness and } \\
\text { proficiency in L2 listening. Applied Linguistics, 26/1,70-89. }\end{array}$ \\
\hline 4 & Forman, R. (2011). Humorous language play in a Thai EFL classroom. Applied Linguistics, 32(5), 541-565. \\
\hline 5 & Field, J. (2005). Intelligibility and the listener: The role of lexical stress. TESOL Quarterly, 39(3), 399-423. \\
\hline 6 & $\begin{array}{l}\text { Field, J. (2008). Bricks or Mortar: Which parts of the input does a second language listener rely on?. TESOL } \\
\text { Quarterly, 42(3), 411-433. }\end{array}$ \\
\hline 7 & $\begin{array}{l}\text { Folse, K. (2006). The effect of type of written exercise on L2 vocabulary retention. TESOL Quarterly, 40(2), } \\
273-283 .\end{array}$ \\
\hline 8 & Radwan, A. (2005). The effectiveness of explicit attention to form in language learning. System, 33, 69-87. \\
\hline 9 & $\begin{array}{l}\text { Goker, S.D. (2006). Impact of peer coaching on self-efficacy and instructional skills in TEFL teacher } \\
\text { education. System, 34, 239-254. }\end{array}$ \\
\hline 10 & $\begin{array}{l}\text { Grainger, P. (2005). Second language learning strategies and Japanese: Does orthography make a difference?. } \\
\text { System, 33, 327-339. }\end{array}$ \\
\hline 11 & $\begin{array}{l}\text { Alptekin, C. (2006). Cultural familiarity in inferential literal comprehension in L2 reading. System, 34, 494- } \\
508 .\end{array}$ \\
\hline 12 & $\begin{array}{l}\text { Lim, J. (2006). Method sections of management research articles: A pedagogically motivated qualitative } \\
\text { study. English for Specific Purposes, 25, 282-309. }\end{array}$ \\
\hline 13 & $\begin{array}{l}\text { Ozturk, I. (2007). The textual organisation of research article introductions in applied linguistics: Variability } \\
\text { within a single discipline. English for Specific Purposes, 26, 25-38. }\end{array}$ \\
\hline 14 & $\begin{array}{l}\text { Cheng, A. (2008). Individualized engagement with genre in academic literacy tasks. English for Specific } \\
\text { Purposes, 27, 387-411. }\end{array}$ \\
\hline 15 & $\begin{array}{l}\text { Rothman, J. (2009). Pragmatic deficits with syntactic consequences? L2 pronominal subjects and the syntax- } \\
\text { pragmatics interface. Journal of Pragmatics, 41, 951-973. }\end{array}$ \\
\hline 16 & $\begin{array}{l}\text { Hu, G., \& Cao, F. (2011). Hedging and boosting in abstracts of applied linguistics articles: A comparative } \\
\text { study of English- and Chinese- medium journal. Journal of Pragmatics, 43, 2795-2809. }\end{array}$ \\
\hline
\end{tabular}

